\title{
Impact of invasive grasses on Cerrado under natural regeneration
}

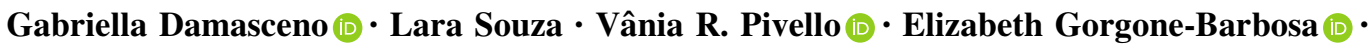 \\ Paula Z. Giroldo $\cdot$ Alessandra Fidelis $(\mathbb{D}$
}

Received: 3 April 2017/ Accepted: 21 July 2018/Published online: 28 July 2018

(C) Springer Nature Switzerland AG 2018

\begin{abstract}
Cerrado is the Brazilian neotropical savanna threatened by invasive African grasses. We aimed to quantify the impact of invasive Melinis minutiflora and Urochloa brizantha on the cover of different functional groups (native graminoids, forbs, shrubs) and the structure (bare soil and the cover of natives' and invasives' dead biomass) of regenerating plant communities. We hypothesized that the impact of invasives would be negative and more pronounced in the rainy period, given the great influence of seasonality in savannas. In three community types (non-invaded, invaded by M. minutiflora and invaded by $U$. brizantha) we evaluated the cover of functional
\end{abstract}

Electronic supplementary material The online version of this article (https://doi.org/10.1007/s10530-018-1800-6) contains supplementary material, which is available to authorized users.

G. Damasceno $(\bowtie) \cdot$ E. Gorgone-Barbosa · A. Fidelis Laboratory of Vegetation Ecology, Instituto de Biociências, Universidade Estadual Paulista (UNESP), Rio Claro. Av. 24A, 1515, Rio Claro 13506-900, Brazil e-mail: fariadamasceno@gmail.com

L. Souza

Oklahoma Biological Survey \& Department of Microbiology and Plant Biology, University of Oklahoma, 111 E. Chesapeake Street, Norman, OK 73019-0390, USA

V. R. Pivello · P. Z. Giroldo

Departamento de Ecologia, Universidade de São Paulo, Rua do Matão, Trav. 14, 321, São Paulo 05508-900, Brazil groups and structural components by sampling 120 $1 \mathrm{~m} \times 1 \mathrm{~m}$ plots, four times a year. Using the Cohen's $\mathrm{D}$ impact index, we showed that both invasive species reduced the cover of all native functional groups, decreased bare soil and increased total dead cover. Greatest effects occurred when M. minutiflora was present. M. minutiflora's impact on total graminoids varied from positive in the Early-Dry season to negative in the Mid-Dry season, while the negative impact of $U$. brizantha on bare soil became more pronounced from the dry to the rainy season. Differences in the impacts caused by the invasive species are probably due to the large biomass produced by $M$. minutiflora versus the fast colonization and soil occupancy by $U$. brizantha. Overall, invaded versus non-invaded communities differed in structure, as well as both invaded communities differed from each other. Our results demonstrate the need to control these species for conservation and restoration of Cerrado ecosystems.

Keywords Biodiversity conservation · Community restoration $\cdot$ Melinis minutiflora $\cdot$ Neotropical savanna $\cdot$ Urochloa brizantha 


\section{Introduction}

Introduced grasses can negatively affect grassland biodiversity and function (Flory and Clay 2010). Worldwide, this type of biological invasion is often caused by African grass species (Reed et al. 2005; Baruch et al. 1989; Rossiter et al. 2004; Pivello et al. 1999a). In temperate grassland prairies, invasive Andropogon bladhii, dominates the system by outcompeting the former commonly occurring native species, Andropogon gerardii, consequently altering the fire cycle (Reed et al. 2005). In the Venezuelan savannas, invasive $M$. minutiflora displaces native species due to its quick growth dynamics, phenology and biomass allocation (Baruch et al. 1989). In Australian savannas, invasive Andropogon gayanus alters fire regime, nutrient cycling and the use of water, thus affecting the richness and abundance of the understory functional groups and pushing the savanna to alternative stable states (Rossiter et al. 2004; Brooks et al. 2010). Furthermore, in the Cerrado (Neotropical savanna), invasive $\mathrm{C}_{4}$ African species like M. minutiflora P. Beauv. (molasses grass) and Urochloa spp. are responsible for both the decline and loss of biodiversity (Pivello et al. 1999a, b; Durigan et al. 2007). The release of allelopathic compounds by Urochloa species (Barbosa et al. 2008; Oliveira et al. 2016) and the increased fuel load (mostly composed of dead biomass; Gorgone-Barbosa et al. 2015) also contribute to the alteration of fire behavior, as well as the dynamics of the native community, thus increasing the risk of wildfires (Hoffmann et al. 2004).

Also, in areas undergoing a regeneration process, invasive grasses can hinder the vegetation recovery (Durigan et al. 1999; Hoffmann and Haridasan 2008) despite the Cerrado's high resilience (Hoffmann 1998; Barreira et al. 2000; de Abreu et al. 2011; Pilon et al. 2018). Therefore, the invasive African grasses not only impact and decrease diversity in the Cerrado, but can be considered one of the most important biotic filters for the regeneration and restoration of those native systems (da Silveira et al. 2013). The Cerrado, like other tropical savannas, is characterized by strong seasonality, which has selected for particular physiological characteristics and therefore tailored community structure (Eiten 1972; Coutinho 1990; Franco 2002). As a result, the majority of the herbaceous layer dries out in the dry season, and resumes growing as environmental conditions become favorable during the wet season (Munhoz and Felfili 2005). Consequently, plant communities in the Cerrado are very dynamic, with vegetation structure (proportion of live to dead biomass) shifting over the year (Batmanian and Haridasan 1985), what could also cause seasonal variations in the impact of invasive grasses on native plant communities composition, structure and dynamics intra-annually.

In this study we aimed to (1) quantify the ecological impact of M. minutiflora and Urochloa brizantha on the native community structure of an open Cerrado under natural regeneration post Pinus caribeaea removal; and (2) quantify the effect of intra-annual seasonality on the ecological impact of both $M$. minutiflora and $U$. brizantha. We hypothesized that the invasive grasses would differently reduce the cover of functional groups of native plants, but the magnitude of such negative impacts would be greater for native graminoids due to greater overlap in resources and conditions relative to the invasive graminoids. Additionally, we hypothesized that the ecological impact of both invasive species would be greater in the rainy period, when vegetation growth is at its peak (Gorgone-Barbosa 2016; Damasceno et al. unpublished data). As a consequence of invasive species impacts, the functional groups and structure of native communities would be altered, thus leading to dissimilarity in the invaded versus non-invaded communities. Furthermore, invasive grass identity would lead to functional and structural dissimilarity between the two invaded communities.

\section{Materials and methods}

Study area

The study was conducted at the Itirapina Ecological Station (EEI, $22^{\circ} 11^{\prime}-22^{\circ} 15^{\prime} \mathrm{S}$ and $47^{\circ} 45^{\prime}-48^{\circ} 00 \mathrm{~W}$; 710-830 m a.s.l.) in São Paulo State, Brazil (Zanchetta et al. 2006). Most of the area is composed of grasslands and open physiognomies of the Cerrado: dominant herbaceous layer with forbs and $\mathrm{C}_{4}$ grasses, scattered shrubs and dwarf trees. The climate is mesothermic with a marked dry season from April to September; mean annual temperature is $21.9^{\circ} \mathrm{C}$ and mean annual precipitation is $1459 \mathrm{~mm}$. The dominant soil type is Arenosol (Zanchetta et al. 2006). 
The study site is 33 ha, and until the year 2000 it was planted with the exotic Pinus caribaea var. hondurensis. After that, pine trees were removed, grazing was excluded, fire was suppressed, and the area has been left to natural regeneration. However, at the beginning of this study there wasn't a remaining layer of pine needles on the ground anymore. Melinis minutiflora and Urochloa brizantha have invaded the area, and patches of these species can be found incorporated into the native vegetation matrix, varying in size (250 $\left.\mathrm{m}^{2}-2 \mathrm{ha}\right)$ and proximity (5-100 $\mathrm{m}$ apart).

\section{Data acquisition}

Vegetation sampling was carried out in three communities, dominated by (1) M. minutiflora P. Beauv., (2) $U$. brizantha (Hochst. ex A. Rich.) R.D. Webster and (3) native species. We selected four large patches with the minimum size of $20 \times 20 \mathrm{~m}$ dominated by each of the two invasive species (at least $70 \%$ of cover) and four of these patches with only native species (in total, 12 large patches). In each large patch we randomly established 10 plots of $1 \times 1 \mathrm{~m}$ (40 plots/community, total of 120 plots, with a minimum distance of $2 \mathrm{~m}$ between plots) avoiding termites, ant nests, armadillo holes and large areas of bare soil. Using a modified Braun-Blanquet method of quadrat frames (Wikum and Shanholtzer 1978) we evaluated in each plot the percentage cover (intervals of 5\%) of community structural parameters: bare soil, dead plant cover (native and invasive dead) and live plant cover according to functional groups-native graminoids, M. minutiflora, $U$. brizantha, forbs and shrubs. We sampled each $1 \mathrm{~m}^{2}$ plot four times within a year: at Early-Dry (May 2014), Mid-Dry (August 2014), LateDry (September 2014) and Mid-Rainy seasons (February 2015), in order to capture all changes in plant communities due to seasonality.

\section{Data analyses}

We used the Cohen's D index to quantify the magnitude of invasive species impact on the community by the pooled ratio of response variables in the invaded plots relative to non-invaded ones (Deeks et al. 2001). The equation for Cohen's D index of a functional component (native graminoids, bare soil, etc.) is given by the formula: $d=\frac{m_{i}-m_{n i}}{\sqrt{\frac{s_{i}^{2}+s_{n i}^{2}}{2}}}$,

where $\mathrm{m}_{i}$ and $\mathrm{m}_{n i}$ are the mean values of a given component in the invaded and non-invaded plots respectively, and $\mathrm{s}_{i}$ and $\mathrm{s}_{n i}$ are the standard deviations of the same functional component in the respective invaded and non-invaded plots. Consequently, a positive value of $\mathrm{d}$ for a given functional component (native graminoids, bare soil, etc.) means that the presence of invasive grasses increased the cover of this functional component in relation to non-invaded plots. On the other hand, a negative value of $d$ means that the invasive species decreased the cover of this component in the invaded communities in relation to the noninvaded ones. Finally, values of Cohen's D index near to zero mean that the invasive grasses had little impact on the given functional component.

As this metric is calculated from the difference of the same component in invaded and non-invaded communities, it is not possible to consider individually the invasive grasses as they are absent in non-invaded communities. Therefore, to include the invasives in the community analysis we created the categories total graminoids (native + invasive graminoid species) and total dead (native + invasive dead cover).

We first calculated the Cohen's D indices for each large patch (using the measurements of its 10 plots) and then compared communities invaded by $M$. minutiflora and by $U$. brizantha using linear mixedeffect models (lme). In this comparison we also considered interaction with seasonality (two-way analysis). Finally, we investigated the effect of seasonality on the Cohen's D index for each species individually. Further, we assessed statistical differences using pairwise post hoc general linear hypothesis tests of Tukey HSD type.

As we were dealing with non-normal multivariate and temporally correlated data, we compared invaded and non-invaded communities with the multivariate non-parametric analysis of variance-PERMANOVA (Anderson 2001) — and Principal Coordinates Analysis (PCoA). We used data from the 120 plots on community structural components (bare soil and dead plants cover), live plant cover according to functional groups (native graminoids, forbs and shrubs), and the two created categories (total graminoids and total dead). As data was expressed as abundance (\%) and is 
therefore upper limited, we used the chord distance to generate the dissimilarity matrix for both analyses (Orlóci 1967). Statistical analyses were performed in the R program (R Development Core Team 2016) with the packages nlme (Pinheiro et al. 2016), vegan (Oksanen et al. 2016) and multcomp (Hothorn et al. 2008).

\section{Results}

Overall, Cohen's D impact indices of both invasive species were negative on the community structural components and functional groups. On regenerating communities, both invasive species had a similar effect $(p=0.32,-1.12 \pm 2.30$ and $-0.86 \pm 1.77$ for $M$. minutiflora and $U$. brizantha respectively; mean $\pm \mathrm{SD}$ for all results). The impact of M. minutiflora and $U$. brizantha differed for bare soil $(p=0.03 ;-1.94 \pm 0.66$ and $-1.33 \pm 0.77$, respectively) and total dead cover ( $p=0.009 ; 2.93 \pm 1.27$ and $1.90 \pm 0.86$ ). In both cases, M. minutiflora has a stronger impact than $U$. brizantha: higher increase in the percentage of total dead cover and higher decrease in the percentage of bare soil.

Both invasive species reduced the cover of every native functional group (graminoids, forbs and shrubs) and native dead cover (Fig. 1). The most negatively impacted groups both by M. minutiflora or U. brizantha were the native graminoids (Cohen's D index of $-4.24 \pm 1.45$ and $-3.29 \pm 1.34$, respectively), and the native dead cover, with values of $-3.28 \pm 1.276$ and $-2.70 \pm 0.98$. When considering the categories that include the invasive species (total dead cover and total graminoids) the impact of invasion was positive due to their contribution to both dead and live biomass (Fig. 1).

The negative impact of invasive grasses was not influenced by seasonality when considering structural components and functional groups altogether across time ( $p=0.90$; Table 1). Considering each functional group separately, only the total graminoids varied seasonally in the communities invaded by $M$. minutiflora, from a positive effect $(1.209 \pm 0.606)$ in the Early-Dry period to a negative one $(-2.178 \pm 1.608)$ in the Mid-Dry season ( $p=0.02$; Fig. 1a). For $U$. brizantha plots, a significant difference was detected in the bare soil, which changed from $-0.697 \pm 0.481$ in the Mid-Dry to $-1.998 \pm 0.659$ in the Mid-Rainy season ( $p=0.03$; Fig. 1b).

Thus, the presence of both invasive species led to dissimilarity in structure and functional composition of invaded versus non-invaded communities (PERMANOVA, $p=0.01$ ); and communities invaded by $M$. minutiflora and $U$. brizantha were dissimilar between each other (PERMANOVA, $p=0.04$ ). The PCoA illustrates these patterns by the shift in location of invaded and non-invaded communities in two dimensions (axes), which together explained $71.2 \%$ of the total variation in functional composition (Fig. 2).

\section{Discussion}

Impact of invasive species on functional components

Urochloa brizantha and Melinis minutiflora reduced the cover of bare soil, native functional groups and native dead biomass. Additionally, these impacts were mostly constant over the year, leading to different communities where the invasive species were present. Urochloa spp. and M. minutiflora have been described as very aggressive, and the most common invasive species in Cerrado (Pivello et al. 1999b; Zenni and Ziller 2011; Ziller and Dechoum 2013; Sampaio and Schmidt 2014). Some authors had already shown negative impacts of these species on the invaded systems (Klink 1994; Pivello et al. 1999a; AlmeidaNeto et al. 2010; Martins et al. 2011; Rossi et al. 2014). The presence of $M$. minutiflora, for example, inhibited the establishment of native tree species (Hoffmann and Haridasan 2008), hindering the recovery of degraded areas by increasing its abundance and excluding native species (Martins et al. 2004). It has been shown that these African grasses negatively affect native grasses (Pivello et al. 1999a) and Asteraceae shrubs (AlmeidaNeto et al. 2010). Moreover, Urochloa species may reduce the germination of native species due to the production of allelopathic compounds (Almeida et al. 1997; Barbosa et al. 2008). However, despite describing the effects of African grasses, the above-mentioned studies did not quantify the impact caused by these invasive species nor evaluated their effect on functional groups or according to seasonality.

In this study we verified that the strongest cover reduction caused by $M$. minutiflora and $U$. brizantha 


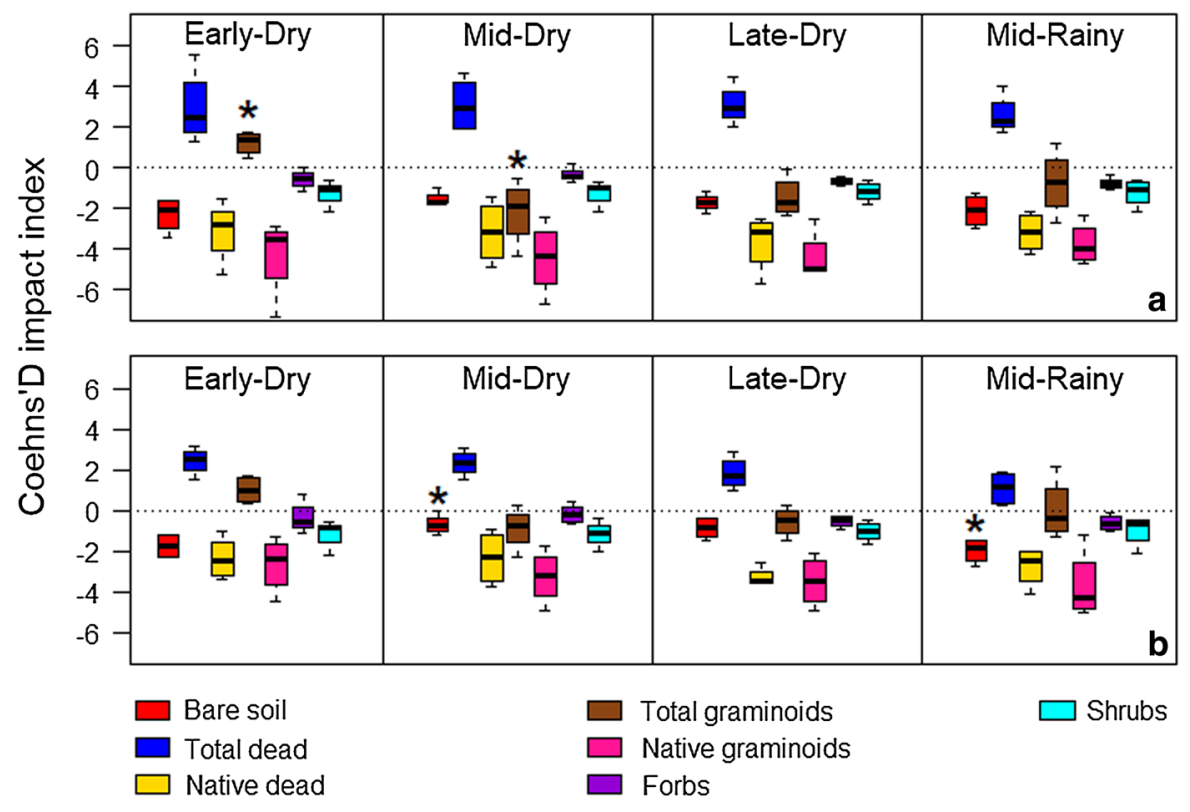

Fig. 1 Cohen's D impact index for Melinis minutiflora (a) and Urochloa brizantha (b) on the community structural components (bare soil, total dead plant cover, native dead plant cover), live plants cover according to functional groups (total graminoids, native graminoids, forbs, and shrubs). Boxplots represent the median (black line), and the first and third quartiles (lower and upper lines, respectively). Statistical differences in Cohen's D impact index among the four seasons (Early-Dry, Mid-Dry, Late-Dry, Mid-Rainy) are marked with asterisk (*)

plant dead cover) and functional groups (native graminoids, forbs and shrubs) altogether
Table 1 Cohen's D impact index (mean \pm SD) of Melinis minutiflora and Urochloa brizantha over a year on regenerating communities considering structural components (bare soil and

\begin{tabular}{llllll}
\hline Invasive & All-time & \multicolumn{2}{l}{ Seasons } & & \\
\cline { 2 - 6 } & & ED & MD & LD & MR \\
\hline Melinis minutiflora & $-1.12 \pm 2.30$ & $-0.90 \pm 2.49$ & $-1.21 \pm 2.40$ & $-1.23 \pm 2.32$ & $-1.13 \pm 2.08$ \\
Urochloa brizantha & $-0.86 \pm 1.77$ & $-0.59 \pm 1.81$ & $-0.75 \pm 1.78$ & $-0.98 \pm 1.77$ & $-1.14 \pm 1.76$
\end{tabular}

No statistical differences were found either between the two species or across seasons for each species ( $p>0.05$ in all cases). ED Early-Dry, $M D$ Mid-Dry, $L D$ Late-Dry, $M R$ Mid-Rainy seasons

was on native graminoids. However, contrary to our hypothesis, seasonality did not enhance or decrease their impact on the vegetation. Both invasive species are perennial and produce high amounts of biomass during the rainy season. Most of that biomass dries out in the dry season but remains attached to the plant (Gorgone-Barbosa 2016; Damasceno and Fidelis unpublished data). In the next rainy season, when water is available, the invasive grasses quickly resprout (Fisher and Kerridge 1996; Zanchi et al. 2009) and bring negative and persistent impacts to the community. The reduction of native graminoids caused by both African grasses that was observed in this study contrasts with others in which functional similarity limited the community invasion by plants from the same functional group (Fargione et al. 2003; Pokorny et al. 2005; Emery 2007; Emery and Gross 2007). However, explanations can be related to factors other than functional redundancy, such as the community richness, or the tridimensional structure given by plant height, above-ground architecture and/or rooting depth, which establish a spatial niche partitioning (Anten and Hirose 1999; Fargione and Tilman 2005; Mozdzer et al. 2016). 


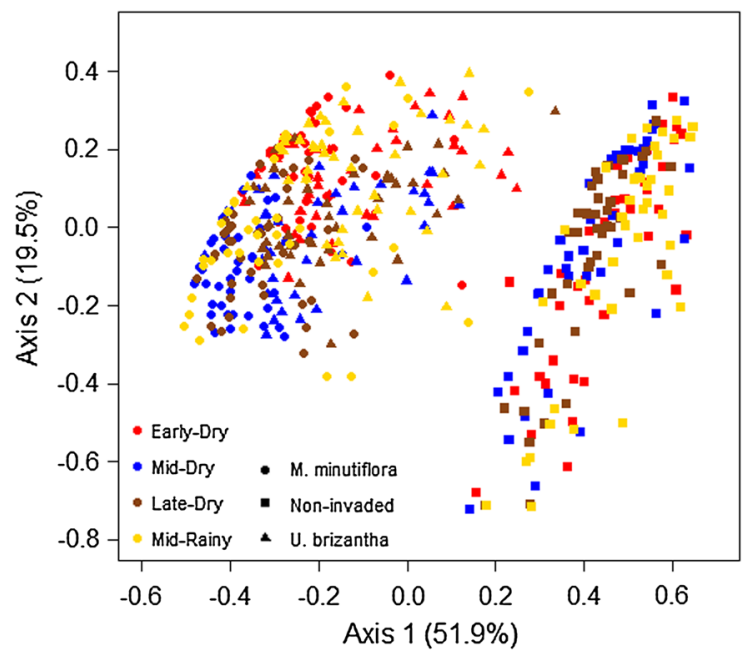

Fig. 2 Principal Coordinates Analysis (PCoA) for the noninvaded communities and communities invaded by Melinis minutiflora or Urochloa brizantha during four periods. Every point represents the position of a plot $\left(1 \mathrm{~m}^{2}\right)$ regarding functional groups composition (total graminoids, native graminoids, forbs and shrubs) and community structure (bare soil, total and native dead cover). Different symbols refer to distinct communities (non-invaded and dominated by each invasive grass) and different colors refer to distinct sampling periods

Moreover, according to phenotypic characteristics that favor the dominance of invasives over native species (Daehler 2003), both M. minutiflora and $U$. brizantha are usually taller than Cerrado grasses, shading the heliophile native graminoids (G. Damasceno, personal observation). Additionally, their architecture may also contribute to this spatial niche partitioning: $M$. minutiflora is a stonoliferous species, a characteristic that could facilitate its soil colonization, while the huge production of biomass by $U$. brizantha would be facilitated by its cespitose architecture.

Furthermore, a temporal niche partitioning can be achieved through different phenological strategies (Engelhardt and Anderson 2011). In our system, invasive species usually flourish and disperse in the dry season (Gorgone-Barbosa et al. unpublished data) while the most dominant native grasses in the area, e.g. Axonopus pressus and Gymnopogon foliosus, reproduce in the rainy season. However, it is common to see Urochloa spp. individuals producing flowers and seeds throughout the year. Both M. minutiflora and $U$. brizantha have evolved under grazing pressure in the African savannas and thus have become good competitors in assimilating nutrients and producing biomass (Baruch et al. 1985; McNaughton 1985; Lannes et al. 2012), and are probably more efficient in resource and water acquisition than the native Cerrado grasses (Rossiter et al. 2004; Mozdzer et al. 2016). They rapidly cover the soil by producing and accumulating biomass, thus hampering conditions for the establishment and development of native plant seedlings (Williams and Baruch 2000; Silva and Haridasan 2007; Hoffmann and Haridasan 2008; Assis 2017).

As a consequence of the decrease in the cover of native grasses cover, the native dead biomass cover was also reduced by both invasive species, which may lead to changes in decomposition rates and nutrient cycling (Vitousek 1992; Vila et al. 2011). Additionally, the amount and quality of dead biomass in a system can alter species dominance in an herbaceous community undergoing succession (Facelli and Facelli 1993). In our study site, the huge production of dead biomass by the invasive species, and their efficiency in colonizing bare soil, hinders the establishment and recovery of native species, especially those from the same functional group, by modifying the microhabitat and the conditions for native species development (Williams and Baruch 2000; Silva and Haridasan 2007; Hoffmann and Haridasan 2008) and by creating a physical barrier that might affect seedling establishment (Flory and Clay 2010). Finally, the greater amount of dead biomass could lead to more intense fires, thus affecting the fire behavior in the invaded communities (Gorgone-Barbosa et al. 2015). These changes could lead to a positive feedback-cycle between invasive grasses and fire, which could be another factor contributing to the success of invasive species over natives (D’Antonio and Vitousek 1992).

Impact on plant communities: implications for restoration and conservation

The production of vast quantities of persistent biomass produced by $M$. minutiflora and $U$. brizantha will probably lead to dissimilar communities at the detriment mainly of native grasses. Our results could be interpreted as an early stage of the differentiation between invaded and non-invaded communities, which may drive modifications in the community composition (species richness, evenness, diversity) or in the relationships among native species (Kuebbing 
et al. 2014), and consequently, in diversity, productivity and seedling establishment (Drake et al. 2008; Kuebbing et al. 2015). In the long-term, the ecosystem processes of the altered communities may be modified, such as changes related to decomposition and nutrient cycling, water conservation, and fire regime (Vitousek 1992; D'Antonio and Vitousek 1992; Hoffmann and Haridasan 2008; Gorgone-Barbosa et al. 2015), which may ultimately lead the system to alternative stable states (Westoby et al. 1989; Brooks et al. 2010). Particularly in ecosystems under a multiplepathway succession, invasive species can alter the trajectory through the loss of species and changed ecosystem properties (Suding et al. 2004; Suding and Gross 2006; Brooks et al. 2010). Moreover, exotic invasive grasses can persist in ecological systems over long periods of time, thus creating the need for management actions to exclude them from the system (D'Antonio and Meyerson 2002). Similar to temperate grasslands, plant invasions by M. minutiflora and Urochloa spp. in the Cerrado can promote the transition from preserved open formations into degraded states (Pivello and Coutinho 1996), ultimately altering the community diversity-stability mechanisms (Wilsey et al. 2014) to a point where a "degraded land" (sensu Pivello and Coutinho 1996) persists. The control or eradication of $M$. minutiflora and $U$. brizantha is thus needed to redefine the trajectory towards restoration of a diverse community where mechanisms of diversity-stability are maintained.

Acknowledgements The authors thank Ana Carolina Ferreira, Cíntia Souza, Evaldo Souza, Giovana Chiari, Heloiza Zirondi, Jonathan Galdi Rosa, Karen Castillioni, Lucas Barbosa, Luis Felipe Daibes, Mariana Dairel, Mariana Rissi, Natacha Silva, Priscilla Sperandio, Rafael Consolmagno, Tamires Zepon and Vagner Zanzarini for helping during the field work, and the staff of the Itirapina Ecological Station for their valuable help during the establishment and maintenance of the experimental plots. G.D. received financial support from Fundação de Amparo à Pesquisa do Estado de São Paulo (FAPESP 2015/10714-6), V.R.P. and A.F. were granted by Conselho Nacional de Desenvolvimento Científico e Tecnológico (CNPq 305253/2015-8 and CNPq 306170/2015-9). This project was funded by Fundação de Amparo à Pesquisa do Estado de São Paulo (FAPESP 2015/06743-0) and the Neotropical Grasslands Conservancy.

\section{Compliance with ethical standards}

Conflict of interest The authors declare that they have no conflict of interest.

\section{References}

Almeida ARP, Lucchesi AA, Abbado MR (1997) Efeito alelopático de espécies de Brachiaria Griseb. sobre algumas leguminosas forrageiras tropicais. II. Avaliações em casa de vegetação. Bol Ind Anim 54:45-54

Almeida-Neto M, Prado PI, Kubota U, Bariani JM, Aguirre GH, Lewinsohn TM (2010) Invasive grasses and native Asteraceae in the Brazilian cerrado. Plant Ecol 209:109-122. https://doi.org/10.1007/s11258-010-9727-8

Anderson MJ (2001) A new method for non-parametric multivariate analysis of variance. Austral Ecol 26:32-46

Anten NPR, Hirose T (1999) Interspecific differences in aboveground growth patterns result in spatial and temporal partitioning of light among species in a tall-grass meadow. J Ecol 87:583-597. https://doi.org/10.1046/j.1365-2745. 1999.00365.x

Barbosa EG, Pivello VR, Meirelles ST (2008) Allelopathic evidence in Brachiaria decumbens and its potential to invade the Brazilian cerrados. Braz Arch Biol Technol 51:825-831. https://doi.org/10.1590/S1516-89132008000 400021

Barreira S, Alvarenga Botelho S, Scolforo JR, Mello JM (2000) Efeitos de diferentes intensidades de corte seletivo sobre a regeneração natural de Cerrado. CERNE 6:40-51

Baruch Z, Ludlow M, Davis R (1985) Photosynthetic responses of native and introduced $\mathrm{C} 4$ grasses from Venezuelan savannas. Oecologia 67:388-393. https://doi.org/10.1007/ BF00384945

Baruch Z, Hernandez ABR, Montilla MG (1989) Dinamica del crecimiento, fenologia y reparticion de biomasa gramineas nativas e introducidas de una sabana neotropical. Ecotropicos 2:1-13

Batmanian GJ, Haridasan M (1985) Primary production and accumulation of nutrients by the ground layer community of cerrado vegetation of central Brazil. Plant Soil 88:437-440. https://doi.org/10.1007/BF02197500

Brooks KJ, Setterfield SA, Douglas MM (2010) Exotic grass invasions: applying a conceptual framework to the dynamics of degradation and restoration in Australia's tropical savannas. Restor Ecol 18:188-197. https://doi.org/ 10.1111/j.1526-100X.2008.00470.x

Coutinho LM (1990) Fire in the ecology of the Brazilian cerrado. In: Goldammer $\mathbf{J}$ (ed) Fire in the tropical biota. Ecological studies, vol 84. Springer, Berlin, pp 82-105

D'Antonio CM, Meyerson LA (2002) Exotic plant species as problems and solutions in ecological restoration. Restor Ecol 10:703-713. https://doi.org/10.1046/j.1526-100X. 2002.01051.x

D’Antonio CM, Vitousek PM (1992) Biological invasions by exotic grasses, the grass/fire cycle, and global change. Annu Rev Ecol Syst 23:63-87

da Silveira ER, de Melo ACG, Contieri WA, Durigan G (2013) Controle de gramíneas exóticas em plantio de restauração de Cerrado. In: Durigan G, Ramos VSR (eds) Manejo Adaptativo: primeiras experiências na restauração de ecossistemas. Páginas e Letras Editora e Gráfica, São Paulo, pp 5-8

Daehler CC (2003) Performance comparisons of co-occurring native and alien invasive plants: implications for 
conservation and restoration. Annu Rev Ecol Evol Syst 34:183-211. https://doi.org/10.1146/132403

de Abreu RCR, de Assis GB, Frison S, Aguirre A, Durigan G (2011) Can native vegetation recover after slash pine cultivation in the Brazilian Savanna? For Ecol Manag 262:1452-1459. https://doi.org/10.1016/j.foreco.2011.06. 046

Deeks JJ, Douglas GA, Michael JB (2001) Statistical methods for examining heterogeneity and combining results from several studies in meta-analysis. In: Egger M, Altman DG, Smith GD (eds) Systematic reviews in health care: metaanalysis in context, 2nd edn. BMJ Publishing Group, London, pp 285-312

Drake JM, Cleland EE, Horner-Devine MC, et al (2008) Do Non-native Plant Species Affect the Shape of Productivitydiversity Relationships? Am Midl Nat 159:55-56. https:// www.jstor.org/stable/20491311

Durigan G, Contieri WA, Franco GADC, Garrido MAO (1999) Indução do processo de regeneração da vegetação de Cerrado em área de pastagem, Assis, SP. Acta Bot Brasilica 12:421-429

Durigan G, Ferreira De Siqueira M, Daher GA, Franco C (2007) Threats to the cerrado remnants. Sci Agric (Piracicaba) 64:355-363. https://doi.org/10.1590/S0103-90162007000 400006

Eiten G (1972) The Cerrado vegetation of Brazil. Bot Rev 38:201-338. https://doi.org/10.1007/BF02859158

Emery SM (2007) Limiting similarity between invaders and dominant species in herbaceous plant communities? J Ecol 95:1027-1035. https://doi.org/10.1111/j.1365-2745.2007. 01274.x

Emery SM, Gross KL (2007) Dominant species identity, not community evennes, regulates invasion in experimental grassland plant communities. Ecology 88:954-964. https:// doi.org/10.1890/06-0568

Engelhardt MJ, Anderson RC (2011) Phenological niche separation from native species increases reproductive success of an invasive species: Alliaria petiolata (Brassicaceae)garlic mustard. J Torrey Bot Soc 138:418-433

Facelli JM, Facelli E (1993) Interactions after death: plant litter controls priority effects in a successional plant community. Oecologia 95:277-282. https://doi.org/10.1007/BF003 23500

Fargione J, Tilman D (2005) Niche differences in phenology and rooting depth promote coexistence with a dominant $\mathrm{C} 4$ bunchgrass. Oecologia 143:598-606. https://doi.org/10. 1007/s00442-005-0010-y

Fargione J, Brown CS, Tilman D (2003) Community assembly and invasion: an experimental test of neutral versus niche processes. Proc Natl Acad Sci USA 100:8916-8920. https://doi.org/10.1073/pnas.1033107100

Fisher MJ, Kerridge PC (1996) The agronomy and physiology of Brachiaria species. In: Miles JW, Mass BL, Valle CB (eds) Brachiaria: Biology, agronomy and improvement. Centro Internacional de Agricultura Tropical (CIAT) and Empresa Brasileira de Pesquisa Agropecuária/Centro Nacional de Pesquisa de Gado de Corte (EMBRAPA/ CNPGC), Cali, pp 43-52

Flory SL, Clay K (2010) Non-native grass invasion suppresses forest succession. Oecologia 164:1029-1038. https://doi. org/10.1007/s00442-010-1697-y
Franco AC (2002) Ecophysiology of wood plants. In: Oliveira PS, Marquis RJ (eds) The Cerrados of Brazil: Ecology and natural history of a neotropical savanna, Columbia University Press, New York, pp. 178-198. www.jstor.org/ stable/10.7312/oliv12042.13, pp 178-200

Gorgone-Barbosa E (2016) A relação entre fogo e uma gramínea invasora no Cerrado: $\mathrm{O}$ fogo pode ser utilizado como uma estratégia de controle? Thesis, Universidade Estadual Paulista "Júlio de Mesquita Filho"

Gorgone-Barbosa E, Pivello VR, Bautista S, Zupo T, Rissi MN, Fidelis A (2015) How can an invasive grass affect fire behavior in a tropical savanna? A community and individual plant level approach. Biol Invasions 17:423-431. https://doi.org/10.1007/s10530-014-0740-z

Hoffmann WA (1998) Post-burn reproduction of woody plants in a neotropical savanna: the relative importance of sexual and vegetative reproduction. J Appl Ecol 35:422-433. https://doi.org/10.1046/j.1365-2664.1998.00321.x

Hoffmann WA, Haridasan M (2008) The invasive grass, Melinis minutiflora, inhibits tree regeneration in a Neotropical savanna. Austral Ecol 33:29-36. https://doi.org/10.1111/j. 1442-9993.2007.01787.x

Hoffmann WA, Hoffmann WA, Lucatelli VMPC, Silva FJ, Azeuedo INC, Marinho MS, Albuquerque AMS, Lopes AO, Moreira SP (2004) Impact of the invasive alien grass Melinis minutiflora at the savanna-forest ecotone in the Brazilian cerrado. Divers Distrib 10:99-103. https://doi. org/10.1111/j.1366-9516.2004.00063.x

Hothorn T, Bretz F, Westfall P (2008) Simultaneous inference in general parametric models. Biom J 50:346-363

Klink CA (1994) Effects of clipping on size and tillering of native and African grasses of the Brazilian savannas (the cerrado). Oikos 70:365-376. https://doi.org/10.2307/ 3545774

Kuebbing SE, Souza L, Sanders NJ (2014) Effects of co-occurring non-native invasive plant species on old-field succession. For Ecol Manag 324:196-204

Kuebbing SE, Classen AT, Sanders NJ, Simberloff D (2015) Above- and below-ground effects of plant diversity depend on species origin: an experimental test with multiple invaders. New Phytol 208:727-735. https://doi.org/10. 1111/nph. 13488

Lannes LS, Bustamante MMC, Edwards PJ, Venterink HO (2012) Alien and endangered plants in the Brazilian cerrado exhibit contrasting relationships with vegetation biomass and N:P stoichiometry. New Phytol 196:816-823. https://doi.org/10.1111/j.1469-8137.2012.04363.x

Martins CR, Leite LL, Haridasan M (2004) Molasses grass (Melinis minutiflora P. Beauv.): an exotic species compromising the recuperation of degraded areas in conservation units. Rev Árvore 28:739-747. https://doi.org/10. 1590/s0100-67622004000500014

Martins CR, Hay JDV, Walter BMT, Proença CEB, Vivaldi LJ (2011) Impact of invasion and management of molasses grass (Melinis minutiflora) on the native vegetation of the Brazilian Savanna. Brazilian J Bot 34:73-90. https://doi. org/10.1590/s0100-84042011000100008

McNaughton SJ (1985) Ecology of a grazing ecosystem: the Serengeti. Ecol Monogr 55:259-294

Mozdzer TJ, Langley JA, Mueller P, Megonigal JP (2016) Deep rooting and global change facilitate spread of invasive 
grass. Biol Invasions 18:2619-2631. https://doi.org/10. 1007/s10530-016-1156-8

Munhoz CBR, Felfili JM (2005) Fenologia do estrato herbáceosubarbustivo de uma comunidade de campo sujo na Fazenda Água Limpa no Distrito Federal, Brasil. Acta Bot Brasilica 19:979-988. https://doi.org/10.1590/S010233062005000400031

Oksanen J, Blanchet FG, Kindt R et al (2016) Vegan: community ecology package. Commun Ecol. Package version

Oliveira APP, Pereira SR, Cândido ACS, Laura VA, Peres MTLP (2016) Can allelopathic grasses limit seed germination and seedling growth of mutambo? A test with two species of Brachiaria grasses. Planta Daninha 34:639-648. https://doi.org/10.1590/s0100-83582016340400003

Orlóci L (1967) An agglomerative method for classification of plant communities. Br Ecol Soc 55:193-206

Pilon NAL, Buisson E, Durigan G (2018) Restoring Brazilian savanna ground layer vegetation by topsoil and hay transfer. Restor Ecol 26:73-81. https://doi.org/10.1111/rec. 12534

Pinheiro J, Bates D, DebRoy S, Sarkar D, R Core Team (2016) nlme: linear and nonlinear mixed effects models. R package version 3.1-131. https://CRAN.R-project.org/ package $=$ nlme

Pivello VR, Coutinho LM (1996) A qualitative successional model to assist in the management of Brazilian cerrados. For Ecol Manag 87:127-138. https://doi.org/10.1016/ S0378-1127(96)03829-7

Pivello VR, Shida CN, Meirelles ST (1999a) Alien grasses in Brazilian savannas: a threat to the biodiversity. Biodivers Conserv 8:1281-1294. https://doi.org/10.1023/A:1008933 305857

Pivello V, Carvalho V, Lopes P (1999b) Abundance and distribution of native and alien grasses in a "Cerrado"(Brazilian Savanna) biological reserve. Biotropica 31:71-82. https://doi.org/10.1111/j.1744-7429.1999.tb0 0117.x

Pokorny ML, Sheley RL, Zabinski CA, Engel RE, Svejcar TJ, Borkowski JJ (2005) Plant functional group diversity as a mechanism for invasion resistance. Restor Ecol 13:448-459. https://doi.org/10.1111/j.1526-100X.2005. 00056.x

R Development Core Team (2016) R: a language and environment for statistical computing. R Foundation for Statistical Computing, Vienna. ISBN 3-900051-07-0. http://www.Rproject.org

Reed HE, Seastedt TR, Blair JM (2005) Ecological consequences of $\mathrm{C} 4$ grass invasion of a $\mathrm{C} 4$ grassland: a dilemma for management. Ecol Appl 15:1560-1569. https://doi.org/ 10.1890/04-0407

Rossi RD, Martins CR, Viana PL, Rodrigues EL, Eugênio JCF (2014) Impact of invasion by molasses grass (Melinis minutiflora P. Beauv.) on native species and on fires in areas of campo-cerrado in Brazil. Acta Bot Brasilica 28:631-637. https://doi.org/10.1590/0102-33062014abb 3390

Rossiter N, Setterfield SA, Douglas MM et al (2004) Exotic grass invasion in the tropical savanna of northern Australia: ecosystem consequences. Fuel 2004:168-171
Sampaio AB, Schmidt IB (2014) Espécies exóticas invasoras em unidades de conservação federais do Brasil. Biodivers Bras 3:32-49

Silva JSO, Haridasan M (2007) Acúmulo de biomassa aérea e concentração de nutrientes em Melinis minutiflora P. Beauv. e gramíneas nativas do cerrado. Rev Bras Botânica 30:337-344. https://doi.org/10.1590/S0100-8404200700 0200016

Suding KN, Gross KL (2006) Modifying native and exotic species richness correlations: the influence of fire and seed addition. Ecol Appl 16:1319-1326. https://doi.org/10. 1016/j.tree.2003.10.005

Suding KN, Gross KL, Houseman GR (2004) Alternative states and positive feedbacks in restoration ecology. Trends Ecol Evol 19:46-53. https://doi.org/10.1016/j.tree.2003.10.005

Vila M, Espinar JL, Hejda M et al (2011) Ecological impacts of invasive alien plants: a meta-analysis of their effects on species, communities and ecosystems. Ecol Lett 14:702-708. https://doi.org/10.1111/j.1461-0248.2011. 01628.x

Vitousek PM (1992) Effects of alien plants on native ecosystems. In: Stone CP, Smith CW, Tunison JT (eds) Alien plant species in native ecosystems of Hawai'i: management and research. University of Hawai'i Cooperative National Park Resources Studies Unit, Honolulu, pp 29-41

Westoby M, Walker B, Noy-Meir I (1989) Opportunistic management for rangelands not at equilibrium. J Range Manag 42:266-274

Wikum DA, Shanholtzer GF (1978) Application of the BraunBlanquet cover-abundance scale for vegetation analysis in land development studies. Environ Manag 2:323-329. https://doi.org/10.1007/BF01866672

Williams DG, Baruch Z (2000) African grass invasion in the Americas: ecosystem consequences and the role of ecophysiology. Biol Invasions 2:123-140. https://doi.org/10. 1023/A: 1010040524588

Wilsey BJ, Daneshgar PP, Hofmockel K, Polley HW (2014) Invaded grassland communities have altered stabilitymaintenance mechanisms but equal stability compared to native communities. Ecol Lett 17:92-100. https://doi.org/ 10.1111/ele. 12213

Zanchetta D, Delgado JM, Silva CEF, Reis CM, Silva Da Luca EF, Fernandes FS, Dutra-Lutgens H, Tannus JLS, Pinheiro LS, Martins MR, Sawaya R (2006) Plano de manejo integrado-Estações Ecológica e Experimental de ItirapinaSP. $1^{\text {a }}$ Revisão. Instituto Florestal

Zanchi FB, Waterloo MJ, Aguiar LJG et al (2009) Estimativa do Índice de Área Foliar (IAF) e Biomassa em pastagem no estado de Rondônia, Brasil. Acta Amazon 39:335-348

Zenni RD, Ziller SR (2011) An overview of invasive plants in Brazil. Rev Bras Botânica 34:431-446. https://doi.org/10. 1590/S0100-84042011000300016

Ziller SR, Dechoum MS (2013) Plantas e vertebrados exóticos invasores em unidades de conservação no Brasil. Biodivers Bras 3:4-31 